\title{
Forest Tends Transformation in the course of Invasion of Mikania micrantha Kunth ex HBK. in Dilli Reserve Forest of Assam - Emphasis on Vegetation Characters
}

\author{
Kuntala Neog Barua ${ }^{*}$, Protul Hazarika and Prodip Kr. Hazarika
}

\author{
Forest Ecology and Climate Change Division, Rain Forest Research Institute, P.Box No: 136, \\ Sotai, Jorhat-785001, Assam, India \\ *Corresponding author
}

\begin{tabular}{|c|c|}
\hline & R S T D \\
\hline & \multirow{5}{*}{$\begin{array}{l}\text { Changes of vegetation pattern of Dilli Reserve Forest under Sivasagar Forest Division, } \\
\text { Assam has been studied owing to invasion of aggressive smothering vine Mikania } \\
\text { micrantha during 2014-2017. Dipterocarpus retusus was the predominant element in the } \\
\text { upper canopy layer of natural forest site which grown gregariously in well drained alluvial } \\
\text { plains of the foothills of Patkai range having IVI of } 13.19 \text { followed by Mesua ferrea } \\
\text { (10.76), Artocarpus chama (10.63) and Vatica lanceaefolia ( } 8.77 \text { ). In contrary, the } \\
\text { Mikania infested forest areas top canopy strata was dominated by deciduous species of } \\
\text { short leafless period viz. Ficus hispida (IVI 14.47), Lagerstroemia speciosa (IVI 12), } \\
\text { Balakata baccata (11.49) etc. Tree density of infested site was recorded as } 1276 / \text { ha. and } \\
\text { in un-infested natural forest sites it was } 2380 / \text { ha. Highest tree basal area of natural forest } \\
\text { indicated the dominance of more mature large trees of Dipterocarpus and Mesua. Seasonal } \\
\text { fluctuation of } M \text {. micrantha revealed that the weed vigorously invaded in the surrounding } \\
\text { forest edges and open canopy areas with highest population density }\left(9.28 \mathrm{~m}^{2} \text { ) in post }\right. \\
\text { monsoon season. It alone constituted } 18.01 \% \text { of herb layer contained the regenerating tree } \\
\text { seedlings and other herb species. Diversity index values were comparatively high in un- } \\
\text { infested sites. Only } 43.81 \% \text { similarity was observed between un-infested and infested } \\
\text { forest sites. Smothering effect of fast growing vine have severe impact in regeneration and } \\
\text { seedling establishment of indigenous tree species mainly in periphery and open canopy } \\
\text { areas. They triggered the deciduous species usually, which altered the forest scenario in } \\
\text { near future. }\end{array}$} \\
\hline $\begin{array}{l}\text { K e y w o r d s } \\
\text { Vegetation characters, } \\
\text { Alteration, Mikania } \\
\text { micrantha invasion, D }\end{array}$ & \\
\hline Article Info & \\
\hline & \\
\hline & \\
\hline
\end{tabular}

\section{Introduction}

Biodiversity is essential for the ecosystem function and stability (Singh, 2002). Inventorisation of biodiversity is greatest important to planning of forest management. The forest diversity and dynamics was determined by various environmental changes.
Distribution and abundance pattern of the species influences the floristic diversity of any forest site (Palit and Chandra, 2012). Species richness of a forest is governed by a diverse biotic and a biotic factors (Hustan, 1994). Habitat destruction, over exploitation, environmental pollution and alien invasion are the main causes of biodiversity loss (UNEP, 
2001). Pimm (1986) stated that forest community is changes due to habitat fragmentation or invasion of foreign species. The invasive species differ from native one, on their requirements and more consumption that may cause changes in soil structure, profile, decomposition rate, moisture and nutrient content. Therefore, exotic invasion is a severe threat for conservation and sustainable use of biodiversity.

Mikania micrantha Kunth ex HBK. is a very fast growing perennial smothering vine of Central and South American nativity, now a ever-increasing menace to natural forests and plantation sites in tropics and sub tropics (Holm et al.,1977). In NE India, this species is considered as one of the most troublesome weeds in forest and non-forest areas and its role in degrading productivity has been felt since its introduction in the World War-II. (Parker 1978 and Palit, 1981). Recently, the open sunny patches of Dilli Reserve Forest of upper Assam were severely infested by $M$. micrantha which causing hazards to native vegetation. Various anthropogenic disturbances, forest fragmentation coupled with such exotic invasion have posed direct threat to the unique biodiversity of this forest. Hence, the present study was undertaken to evaluate the impact of $M$. micrantha on floristic diversity and vegetation pattern in Dilli Reserve Forest of Assam.

\section{Materials and Methods}

\section{Study site}

Dilli Reserved Forest located in Sivasagar district of Assam in the foothill of the Patkai range between $27^{0} 4^{\prime} 13.91 " \mathrm{~N}$ to $27^{0} 8^{\prime} 41.39^{\prime \prime}$ $\mathrm{N}$ and $95^{\circ} 17^{\prime} 25.40^{\prime \prime} \mathrm{E}$ to $95^{\circ} 21^{\prime} 56.07^{\prime \prime} \mathrm{E}$, belongs to Assam Valley Tropical Wet Evergreen Forest under the Eastern Himalayan biodiversity hotspot (Figure 1). It is a part of Jeypore-Dehing forest landscape and the area is comprised of $16.7 \mathrm{sq} \mathrm{km}$ (3108 ha.), with elevation of 179 to $197 \mathrm{~m}$ above MSL. The forest is in the track of alluvial formation over Tertiary sand stone and shale, terrain is more or less flat with a gentle slope from southeastern part. The vegetation of the forest is semi evergreen and deciduous components enriched with maximum biodiversity of the undulating hill ranges of Arunachal Pradesh assembly the formation of Assam Valley. Soil sandy loam, $\mathrm{pH}$ ranges from 4.42 to 5.04 the climate distinguished as humid sub-tropical monsonic type. Average annual rainfall is $2191.28 \mathrm{~mm}$ received from the southwest monsoon during June -Aug. Summer runs from mid-April to August, July is the hottest month and the maximum temperature ranges between $19.5^{\circ} \mathrm{C}$ to $33.38^{\circ} \mathrm{C}$. Winter extends from December to mid-February, minimum temperature ranges between $8.2^{\circ} \mathrm{C}$ to $25.79^{\circ} \mathrm{C}$ and January is the coldest month. The average relative humidity was recorded as $79.70 \%$ during the study period and highest $98.84 \%$ observed in the month of June.

\section{Methodology}

Field survey was carried out during the period of 2014-2017 for floristic enumeration and vegetation study. The Forest was divided into two sites based on disturbance intensity of invasive weed $M$. micrantha represented as

\section{Un-infested site; 2. Infested site}

Survey was carried out by randomly lined 25 quadrats of $10 \mathrm{~m} \times 10 \mathrm{~m}$ for tree species, one hundred quadrats of $5 \mathrm{~m} \quad \mathrm{x} 5 \mathrm{~m}$ for shrub/saplings and 125 quadrats of $1 \mathrm{~m} \times 1 \mathrm{~m}$ for herb/seedlings in each site. The plants having more than $6 \mathrm{ft}$. height were considered as tree, plants having height of above $2.6 \mathrm{ft}$. were regarded as shrubs and less than that height were considered as herbs by following Khan (1961). To determine the ecological success of the dominants and co-dominants 
species in both the communities Importance Value Index (IVI) was measured by following Kershew (1973). Diversity index $\left(\mathrm{H}^{\prime}\right)$ and concentration of dominance (CD) were measured by Shannon and Weaver (1963) and Simpson (1949) respectively for site comparison. Species richness was measured by Margalef Index (Margalef, 1958). Evenness index and Equitability (Pielou index) indicated that how evenly the individuals are distributed over the different species in the community. Sorenson and Jaccard's co-efficient and Motyka's index (Magurran, 1988) were used to calculate the similarity co-efficient for the species among the sites.

The plants were identified with the help of local floras (Hooker, 1872-1897; Kanjilal et al., 1934-40; Hajra \& Jain, 1994, Shukla, 1996 and Chowdhury, 2005) and by consulting Herbaria of Botanical Survey of India, Eastern Regional Centre, Shillong, Central National Herbarium, Kolkata. For nomenclature of the taxa, recent Floras have been consulted along with different plant data bases like TROPICOS and PLANT LIST.

\section{Results and Discussion}

\section{Floristic composition and phytosociology}

Enumeration of vegetation pattern of Dilli Reserve Forest indicated that a total of 406 plant species were representing to 283 genera and 103 families belonging to phanerogams and higher cryptogams. Among them trees comprise 45 families 107 genera and 157 species. Euphorbiaceae is the dominant family having 21 species followed by Lauraceae (12 species), Meliaceae (10) and Moraceae (10 species). Parthasarathy (2001) recorded 125 species of $\geq 30 \mathrm{~cm}$ diameter class in tropical wet evergreen forest of Sengaltheri (Western Ghats), which was somewhat comparable with the studied forest. Shrubs were comprised of
70 species under 38 families and 53 genera. 179 species of herbaceous taxa was reported from the forest site under 141 genera and 59 families. Floristic composition of the studied forest has comparatively higher in other tropical semi evergreen forest of this region. Deb et al., (2011) studied the tree species diversity of Namdapha National Park, Arunachal Pradesh observed three distinct canopy covers. Lauraceae, Dipterocarpaceae and Euphobiaceae were the dominant family of the forest that showed evidence of typical lowland Evergreen Tropical Rainforest. Dilli Reserve Forest exhibited more or less similar type of vegetation structure and bear nearer microclimates. Dipterocarpous retusus was the predominant tree along with Mesua ferrea, Artocarpus chama that grown gregariously on well drained alluvial plains of the foothills of the forest. Rich vegetative matter in the soil supported the luxuriant growth of Dipterocarp and Mesua.

The vegetation of the un-infested natural forest site was identified as of Tropical Moist evergreen and mixed semi-evergreen forest. Trees are the predominant life form in the forest ecosystem. The luxuriant DipterocarpMesua formation recognized the forests ecologically and economically as a vital position (Plate-1). Majestic growth of tree fern and fern allies found along the damp shady groove indicates the old land history of the forests. Two 'Least Concern' threatened gymnosperm species Gnetum gnemon and $G$. montanum in the IUCN Red List of 2011 were distributed in the shady areas of the forest. The trees were festooned with climbers, lianas and epiphytic fern as well as orchids. Some of the tree species found in the forest comes under IUCN red list high risk categories viz. Dipterocarpous retusus, Ailanthus integrifolia, Michelia nilagirica, Garcinia indica. Mangifera sylvatica. Wild Musa species viz. Musa acuminate, M. bulbisiana and $M$. rosacea were the dominant features 
formed bunch in the damp forest grove and swamp areas along with thickets of Calamus species. In the upper canopy layer of natural forest site $D$. retusus was the leading species having IVI of 13.19 followed by Mesua ferrea (10.76), Artocarpus chama (10.63), Vatica lanceaefolia (8.77). Highly populated seedlings and Saplings of D. retusus, $M$. ferrea, A. chama and Magnolia hodgsonii were intermingled with them. Creation of gaps and consequent reduction of canopy cover favoured the growth of invasive species. In the Mikania infested forest areas top canopy strata was predominated by deciduous species of short leafless period such as Ficus hispida (IVI 14.47), Lagerstroemia speciosa (IVI 12), Balakata baccata (11.49) (Figure 2).

Tree fern species Cyathea spinulosa (IVI 43.30) was the dominant species in shrub strata in natural forest site along with Leea asiatica (IVI 36.78) and Musaenda roxburghii (IVI 23.90). Whereas, in infested forest site Croton caudatus (IVI 51.12),
Combretum acuminatum (IVI 29.52), Litsea salicifolia (IVI 25.58) and Chromolaena odorata (IVI 24.05) were the major element in the site. Phytosociological study in herbaceous taxa revealed that Abacopteris lahimpurensis (IVI 46.07), Schoenoplectilla juncoides (IVI 35.38), Selaginella biformis (IVI 19.32) were prominant in the humid forest floor mix together with highly occupied seedlings of $D$. retusus and $M$. ferrea. On the other hand, in infested forest site $M$. micrantha (IVI 64.44) expressed highest dominancy along with Oplismenus burmannii (IVI 14.03) and Spermacoce hispida (IVI 13.21) (Figure 2).

Variation of tree density and basal areas of infested and un-infested forest sites were quite prominent. Tree density of infested site was recorded as 1276 /ha. and in un-infested natural forest sites it was 2380/ha. Highest basal area of the trees in natural forest site indicated the dominance of more mature old large trees of Dipterocarpus and Mesua formation (Figure 3).

Fig.1 Map of Dilli Reserve Forest

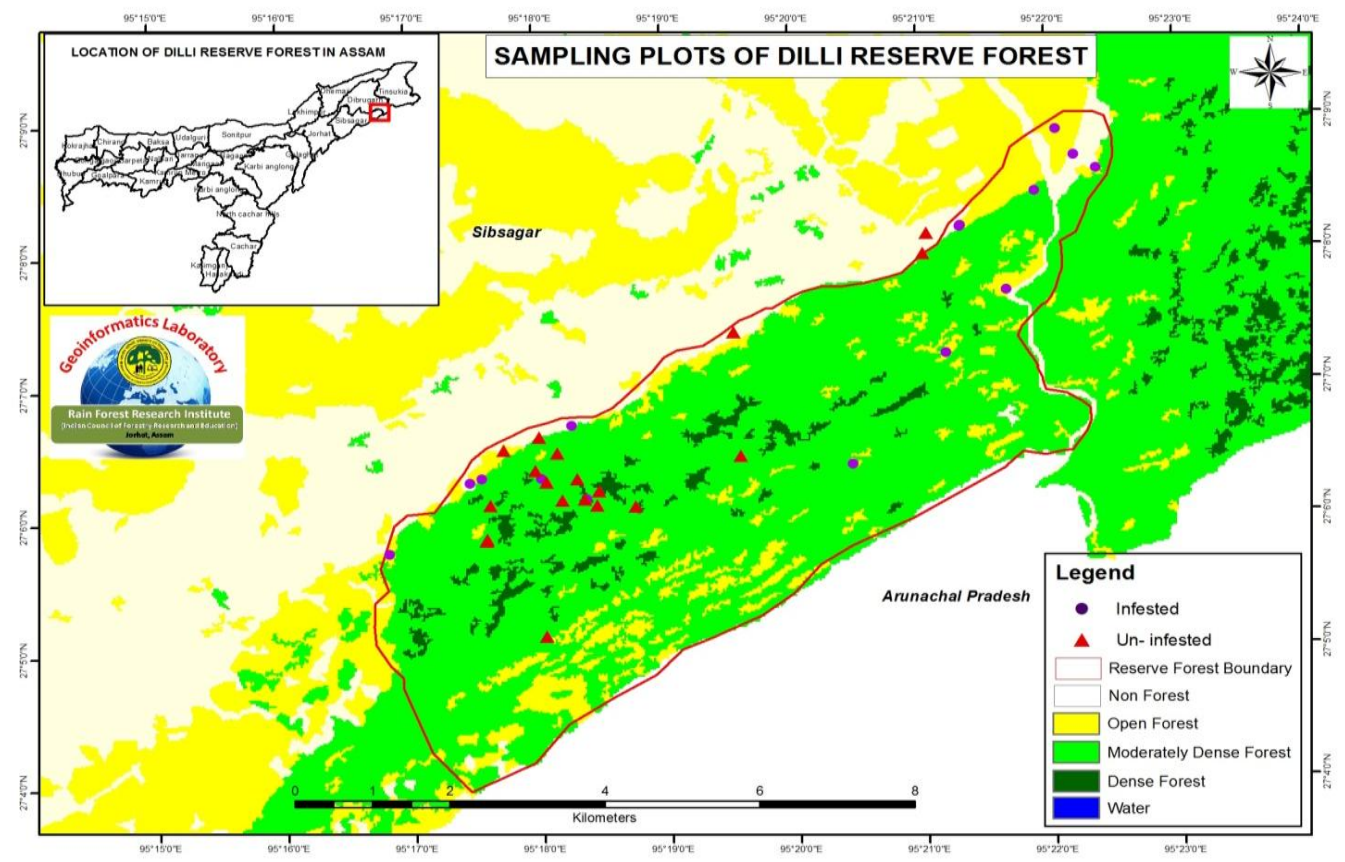


Fig.2 Importance Value Index of top ten species in different strata level

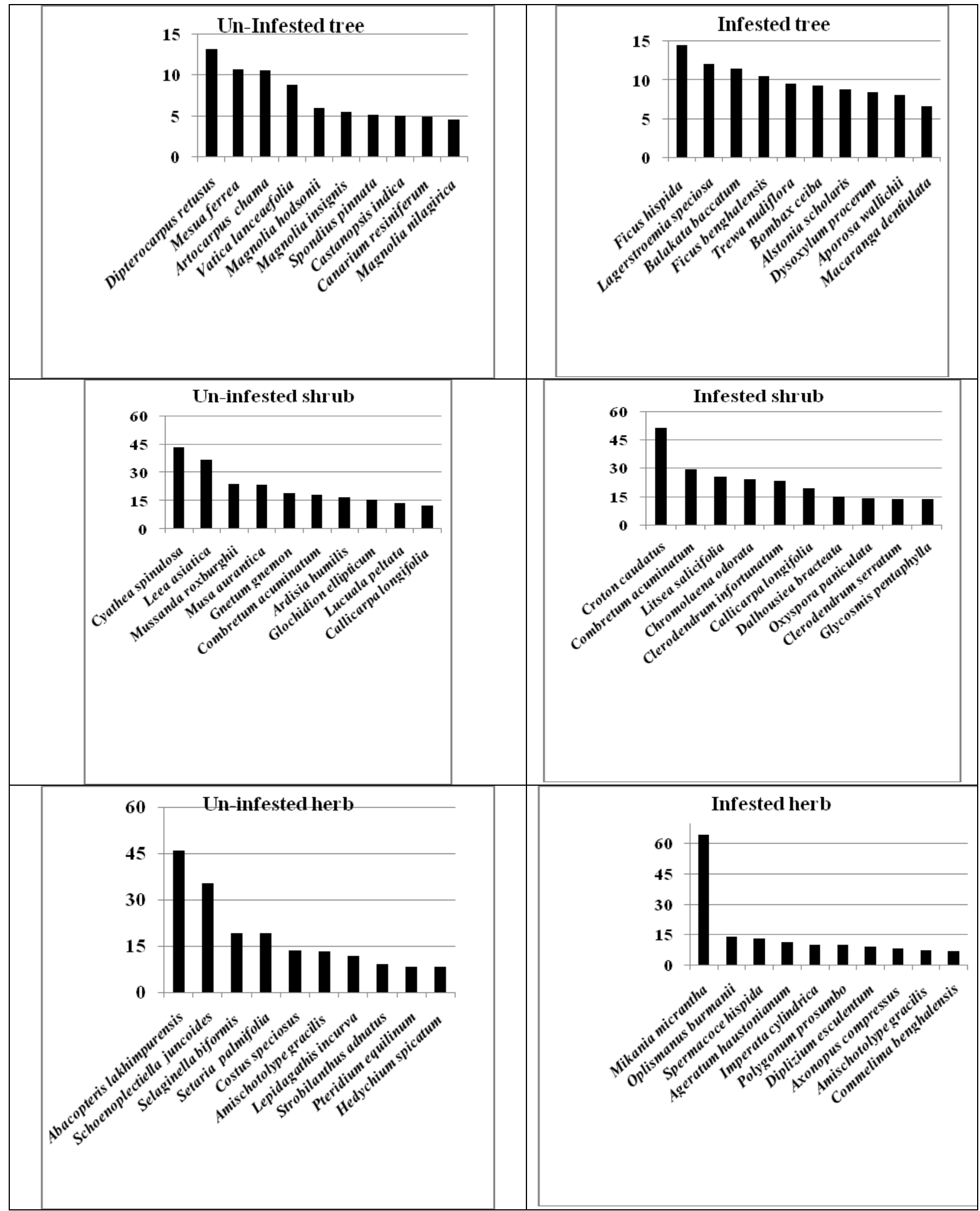


Fig.3 Comparative study of tree density and basal area of infested and un-infested forest sites
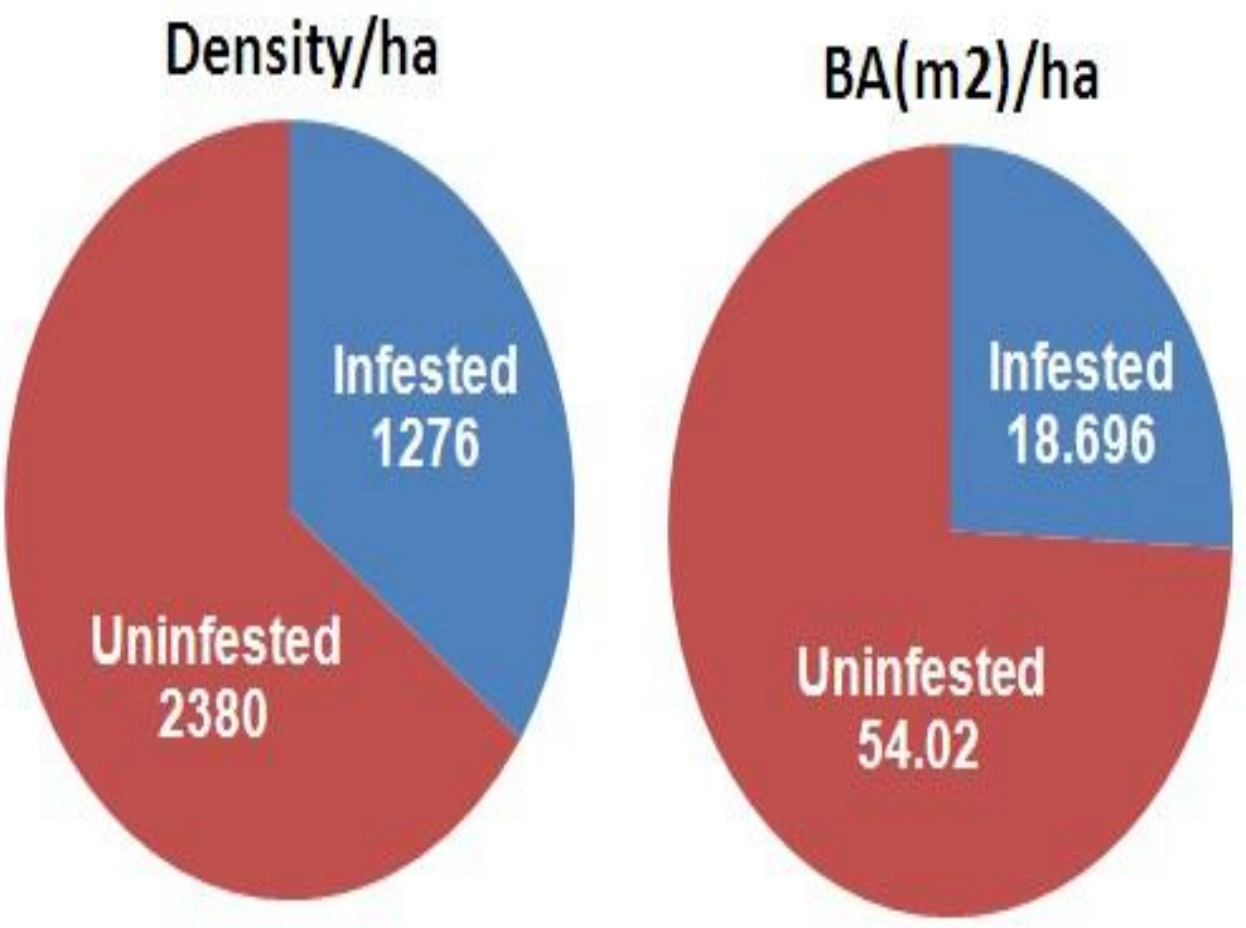

Fig.4 Seasonal changes of population density and IVI of Mikania micrantha

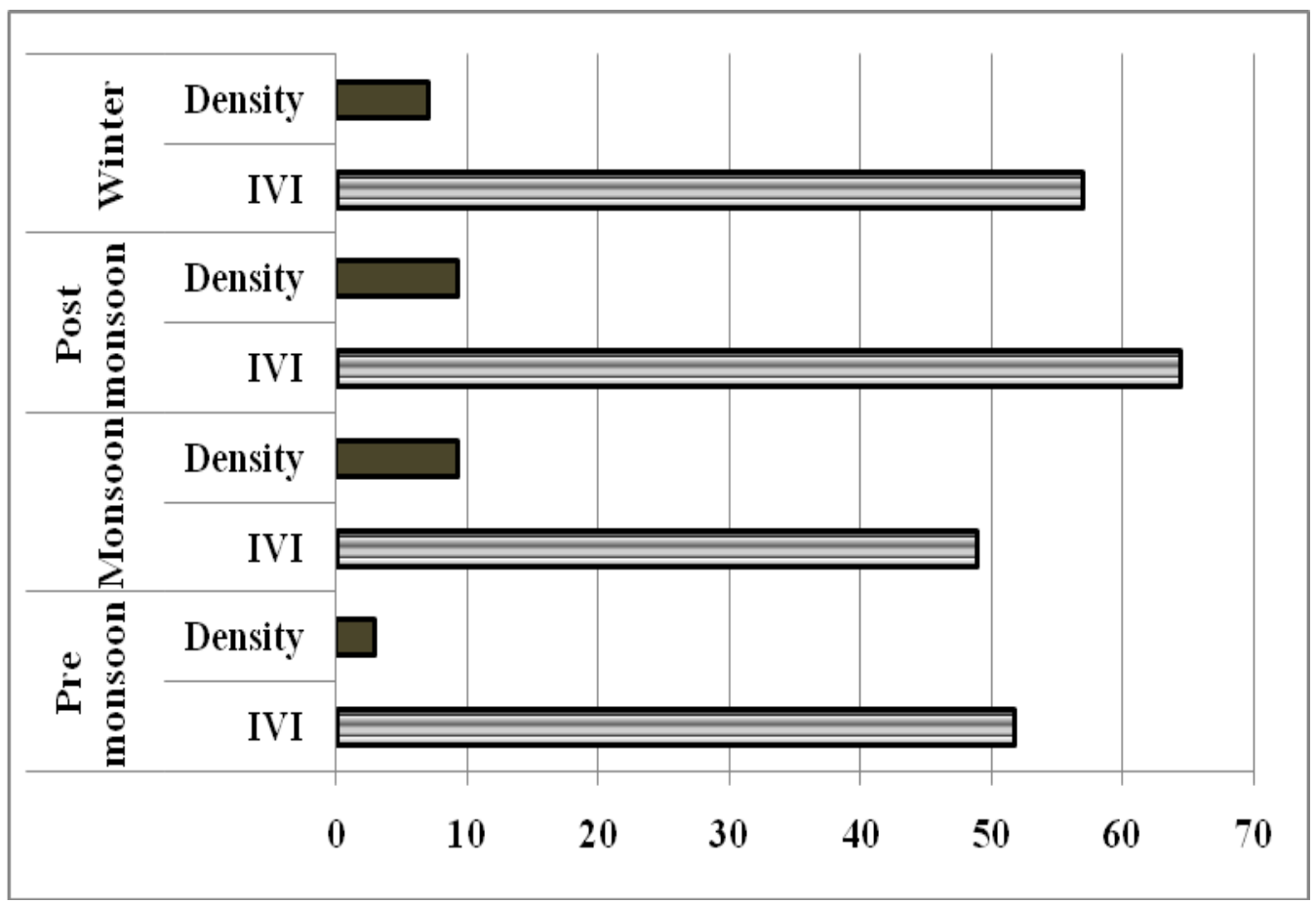


Plate.1 Glimpses of Dilli Forests Reserve
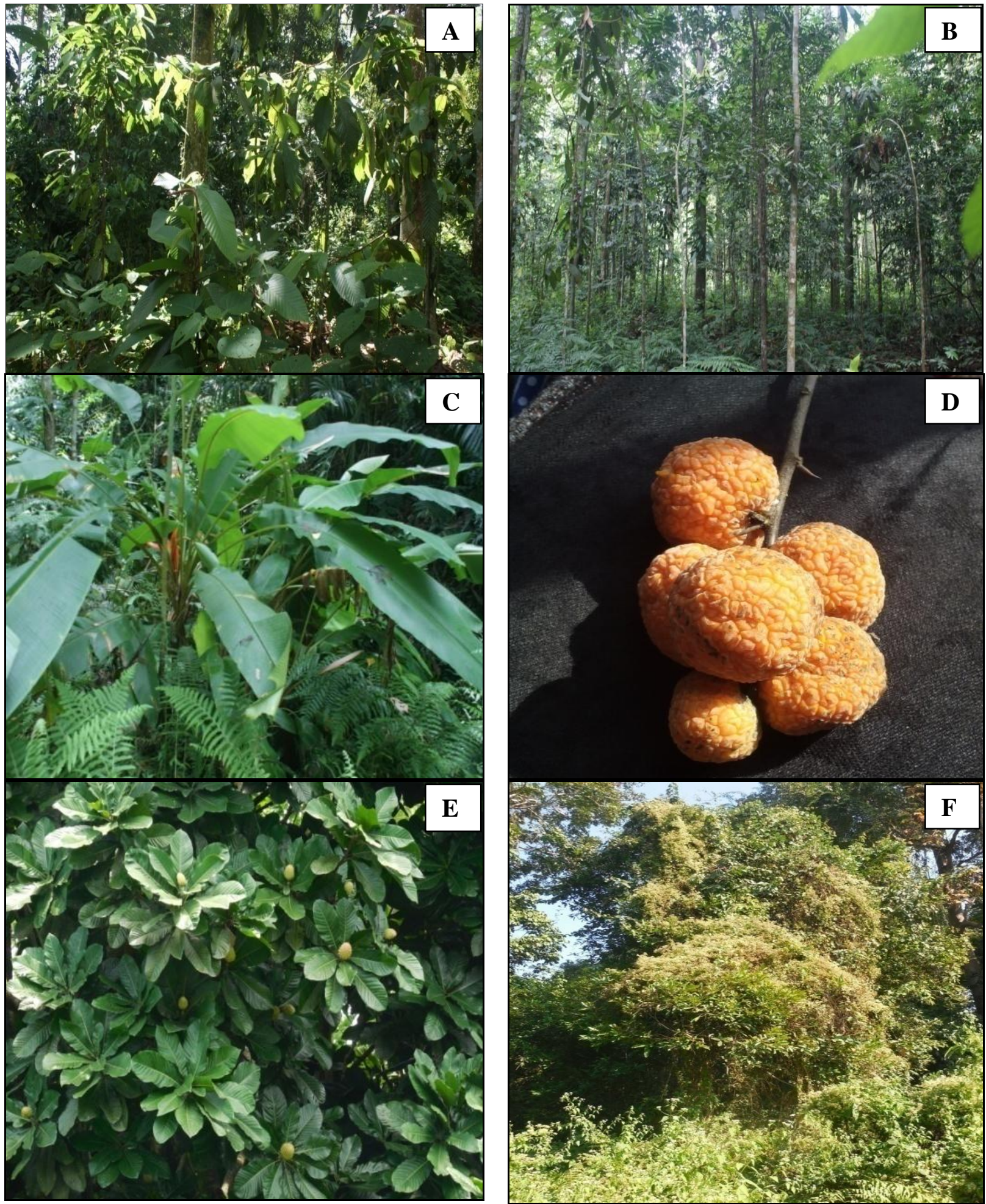

A. Dipterocarp forest showing natural regeneration B. View of Dipterocarp-Mesua association C. Musa aurantica G.Mann ex Baker D. Maclura cochinchinensis Corne. E. Magnolia hodgsonii Keng. F. Invasion of Mikania micrantha in open canopy site 
Table.1 Different indices of Dilli Reserve Forest

\begin{tabular}{|l|c|c|c|c|c|c|c|}
\multicolumn{1}{|c}{ Index } & $\begin{array}{c}\text { Forest } \\
\text { site }\end{array}$ & Tree & Shrub & \multicolumn{4}{c|}{ Herb } \\
\cline { 5 - 8 } Species Diversity & Infested & 3.92 & 3.47 & 2.01 & 3.33 & 3.48 & 1.51 \\
\hline Index (H') & Un-infested & 4.59 & 2.73 & 2.03 & 4.46 & 3.68 & 4.08 \\
\hline Dominance & Infested & 0.02 & 0.07 & 0.05 & 0.09 & 0.04 & 0.02 \\
& Un-infested & 0.01 & 0.09 & 0.01 & 0.02 & 0.03 & 0.01 \\
\hline Margalef Index & Infested & 10.05 & 2.77 & 4.66 & 6.55 & 6.16 & 3.62 \\
& Un-infested & 17.70 & 3.50 & 5.26 & 5.85 & 6.18 & 4.57 \\
\hline Evenness Index & Infested & 0.96 & 2.76 & 0.56 & 0.83 & 0.88 & 0.46 \\
\hline & Un-infested & 0.97 & 0.88 & 0.56 & 1.16 & 0.95 & 1.19 \\
\hline Pilou Index & Infested & 2.21 & 1.20 & 1.30 & 1.92 & 2.04 & 1.06 \\
\hline & Un-infested & 2.23 & 2.02 & 1.25 & 2.67 & 2.19 & 2.74 \\
\hline
\end{tabular}

Table.2 Similarity co-efficient of Dilli Reserve Forest

\begin{tabular}{|l|}
\hline Similarity Index \\
\hline Sorenson co-efficient (Ss) \\
\hline Jaccard's co-efficient (Sj) \\
\hline Motyka's index \\
\hline
\end{tabular}

\begin{tabular}{|l|}
\hline UN-I \\
\hline 0.3046 \\
\hline 0.1797 \\
\hline 43.81 \\
\hline
\end{tabular}

UN: Un-infested

I: Infested

Study on seasonal fluctuation of M. micrantha in infested forest sites revealed that the weed vigorously invaded in the surrounding forest edges and open canopy sites. Population size of Mikania varied noticeably across the seasons. Maximum population density ( 9.3 $\mathrm{m}^{2}$ ) was observed in monsoon season followed by post monsoon season, winter season and minimum value was recorded in the pre monsoon season (2.88). Maximum IVI values of $M$. micrantha were recorded in the post monsoon season (IVI 64.44) followed by winter season (IVI 56.90), pre monsoon season (IVI 51.67) and monsoon season (IVI 48.90) respectively (Figure 4). Sufficient wetness in soil with open sunlight is the possible reasons for the higher density of Mikania in infested forest site. The species alone constituted $18.01 \%$ of herb layer contained all the regenerating tree seedlings and other herb species in full growing season.
The first outbreak of the Mikania was recorded in the month of March and gradually the population was increased and attained maximum range in the month of September to November, that also supported by Puzari et al., (2010).

Biological invasion is considered one of the major threats to species diversity and community structure that considered as the primary cause for global biodiversity loss (Porte et al., 2011). Rajwant et al., (2012) studied the effect of $M$. micrantha invasion and its connection with species richness and soil respiration. They reported that species richness was lower in the area invaded by Mikania compared to not invaded areas and seedling growth was suppressed in the Mikania rhizosphere. Present observation showed that the species richness value of all the tree, shrub and herb strata were declined 
substantially in Mikania infested sites. Islam et al., (2001) reported that in tropical semi evergreen forest of Bangladesh, invasion of Lantana camara influenced rapid turn down of the species. Present study also showed similar trend in invasion of Mikania, that species diversity was significantly lowers in infested sites and species composition was also different. Knight (1975) reported that diversity index was varied up to 5.40 for tropical forest. Studied forest site belonged to Tropical Wet Evergreen Forest and the values of diversity index were found within the ranges. Diversity pattern in the Mikania infested and un-infested forest sites indicated that the values of diversity index were comparatively high in un-infested sites for tree and herb community. Maximum diversity index of herbaceous strata was observed in the monsoon season (4.46) followed by winter, post monsoon and minimum in pre monsoon season (2.03). In the infested site the value was high in post monsoon season (3.48). The concentration of dominance expressed negative correlation with diversity. Considering the value of herb community the dominance was found maximum in monsoon season (0.09). Richness values were varied from 3.62 to 6.55 in infested sites and 4.57 to 6.18 in un-infested sites considering the different seasons. The value of evenness index and equitability index exhibited no significant difference in tree communities of both the infested and un-infested forest (Table 1). Table 2 is associated with the results of paired sites comparisons using binary similarity coefficients. The assessment of Sorenson's similairity co-efficient is higher than Jaccard's co-efficient and the values for Sorenson's and Jaccard's similarity coefficient were 0.3046 and 0.1797 respectively. According to Motyka's index only $43.81 \%$ similarity was observed between un-infested and infested forest sites as both the forest were fairly distinct in their structural compositions. The family Magnoliaceae,
Lauraceae, Dipterocarpaceae etc. were dominated in un-infested natural site. On the other hand in infested area family Moraceae, Lyrthaceae, Rubiaceae and Euphorbiaceae were dominated. Various anthropogenic disturbances change the habitat suitability of many species (Pandey and Shukla, 1999). Occurrence of different Ficus spp., L. speciosa, Trewia nudiflora, B. baccata etc. in the open infested areas and forest boundaries suggested their tolerance and a wide ecological extent.

The overall observation revealed that invasion of Mikania is highly negligible in dense forest of un-infested site. Seedlings or saplings recruitment of some evergreen high valued species viz. $D$. retusus, $M$. ferrea, $V$. lancaefolia, Ailanthus excelsa, Magnolia champaca, $M$. griffithii, $M$. insignis, $M$. montana, $M$. nilgirica etc. were prominent in dense natural forest sites. The smothering effect of this fast growing vine have severe impact in regeneration and seedling establishment of indigenous tree species mainly in periphery areas and open canopy sites. They triggered the deciduous species usually, which was going to be altered the forest scenarioin near future. Intensive protection and maintaining close canopy coverage in natural forest site providing deep shade that may be a preventive precaution against weed invasion drivered by $M$. micrantha.

\section{Acknowledgments}

I would like to express my deep sense of gratitude and sincere thanks to Director, Rain Forest Research Institute, Jorhat for help and support during the project duration. I am grateful to the State Forest Department of Assam, Divisional Forest Officer and the staff of Sivasagar and Dibrugarh for permits to work in the Reserve as well as their support and co-operation. 


\section{References}

Hooker, J.D., 1872-97. Flora of British India I to VII. Reeves and Co, London

Huston, M.A., 1994. Biological Diversity. Cambridge University press, Cambridge

Islam, K.R., M.R. Ahmed, M.K. Bhuiyan and Badruddin, A. 2001. Deforestation effects on vegetative regeneration and soil quality in tropical semi evergreen degraded and protected forests of Bangladesh. 12: 45-56.

Kanjilal, U.N., P.C. Kanjilal, De RN and Das, A. 1934-40. Flora of Assam (in 4 volumes) Govt. of Assam, Shillong

Kershaw, K.K. 1973. Quantitative and dynamic plant Ecology Edward Arnold London Pp.308 Margalef, R. 1958. Information theory in ecology. General systematic. 3: 36-71.

Palit, D., S. Pal and Chanda, S. 2012. Diversity and richness of plants in Darjeeling Himalaya with an eye on Gaddikhana forest beat, Senchal east zone forest range, Derjeeling, Ind. J. For. 35: 39-44.

Pandey, S.K. and Shukla, R.P.1999. Plant diversity and community pattern along the disturbance gradient in plantation forest of sal (Shorea robusta Gaertn.) Curr. Sci. 77: 814-818.

Parthasarathy, N. 2001. Changes in forest composition and structure in three sites of tropical evergreen forest around Sengaltheri, Western Ghats. Curr. Sci. 80(3): 389-393.

Pimm, S.L. 1986 Community structure and stability. In: M. Soul (ed) Conservation Biology: the science of scarcity and diversity. Sinauer, Sunderland, Massachusetts, USA 309-329.

Shannon, C.E. and Weaver, W.1963. The Mathematical Theory of Communication University of Illinois Press, Urbana.

Simpson, E.H. 1949. Measurement of diversity. Nature: 163-688.

\section{How to cite this article:}

Kuntala Neog Barua, Protul Hazarika and Prodip Kr. Hazarika. 2018. Forest Tends Transformation in the course of Invasion of Mikania micrantha Kunth ex HBK. in Dilli Reserve Forest of Assam - Emphasis on Vegetation Characters. Int.J.Curr.Microbiol.App.Sci. 7(09): 1478-1487. doi: https://doi.org/10.20546/ijcmas.2018.709.177 